\title{
Sedimentology and architecture of De Geer moraines in the western Scottish Highlands, and implications for grounding-line glacier \\ dynamics
}

\author{
Nicholas R. Golledge ${ }^{1,2}$, Emrys Phillips ${ }^{1}$ \\ ${ }^{1}$ British Geological Survey, Murchison House, West Mains Road, Edinburgh, EH9 3LA* \\ ${ }^{2}$ Institute of Geography, University of Edinburgh, Drummond Street, Edinburgh, EH8 9XP \\ email n.golledge@bgs.ac.uk, phone +44 1316671000.
}

(*Address for correspondence)

\begin{abstract}
Sedimentary exposures in moraines in a Scottish Highland valley (Glen Chaorach), reveal stacked sequences of bedded and laminated silt, sand and gravel, interspersed or capped with diamicton units. In four examples, faults and folds indicate deformation by glaciotectonism and syndepositional loading. We propose that these sediments were laid down in an ice-dammed lake, close to the last ice margin to occupy this glen. Individual units within cross-valley De Geer moraine ridges are interpreted by comparison with examples from similar environments elsewhere: stratified diamictons containing laminated or bedded lenses are interpreted as subaqueous ice-marginal debris flows; massive fine-grained deposits as hyperconcentrated flows, and massive gravel units as high-density debris flows. Using an allostratigraphic approach we argue that glaciotectonically deformed coarsening-upward sand and gravel sequences that culminate in deposition of subglacial diamicton represent glacier advances into the ice-marginal lake, whereas undisturbed cross-bedded sand and gravel reflects channel or fan deposits laid down during glacier retreat. A flat terrace of bedded sand and gravel at the northern end of Glen Chaorach is interpreted as subaerial glaciofluvial outwash. On the basis of these inferences we propose the following three stage deglacial event chronology for Glen Chaorach. During glacier recession, ice separation and intra-lobe ponding first led to subaquaeous deposition of sorted and unsorted facies. Subsequent glacier stabilisation and ice-marginal oscillation produced glaciotectonic structures in the ice-marginal sediment pile and formed De Geer moraines. Finally, drainage of the ice-dammed lake allowed a subaerial ice-marginal drainage system to become established. Throughout deglaciation, deposition within the lake was characterized by abrupt changes in grain size and in the architecture of individual sediment bodies, reflecting changing delivery paths and sediment supply, and by dynamic
\end{abstract}


margin oscillations typical of water-terminating glaciers.

KEYWORDS: De Geer moraine; ice-dammed lake; grounding line; Younger Dryas; Scotland

SHORT TITLE: De Geer moraines in western Scotland 
'Water-terminating glaciers' are those whose margins are at least partially floating, either in a marine setting or in an ice-marginal lake. They play a key role in ice sheet mass balance by facilitating episodic calving of potentially large volumes of ice - a process evident at the periphery of modern polar ice sheets (Rignot \& Kanagaratnam, 2006) - and may be responsible for greater mass loss from the glacier system than terrestrial margins (Reeh, 1968; Paterson, 1994). Consequently there is a clear need for effective recognition of their signature in the geological record if we are to fully appreciate the behavioural dynamics of former ice masses, and any connection these may have to the climatic or internal forcings that gave rise to them (e.g. Peck et al., 2007).

Glaciers terminating in water become buoyant where the depth of water is sufficient to counter the thickness-dependent normal stress of the ice margin, according to the difference in their relative densities. Extensional flow towards the margin, due to reduced basal drag, as well as flexuring induced by water-level fluctuation, leads to the development of both basal and surface crevasses. Calving occurs when surface crevasse depths equal the height of the ice cliff above water level, and it is the pattern of these major crevasses - or rifts - that controls the location of slab or block detachment (Benn et al., 2007a,b). As a consequence of these specific conditions, floating margins are susceptible to rapid and cyclical fluctuations in the location of their grounding line, giving rise to distinctive landform suites known as De Geer moraines, the form and composition of which reflect the dynamics of the glacier under which they formed. Accurate identification of these diagnostic landforms and sediments therefore plays an important role in identifying water-terminating glacier margins in all previously glaciated terrains, regardless of whether the water body is marine or lacustrine.

Terrestrial De Geer moraines within the limits of the last British Ice Sheet have more-or-less escaped attention until now, especially those formed by Younger Dryas age glaciers. Dix \& Duck (2000) present the only description of such landforms from Scotland, based on seismic stratigraphic data from a sea loch on the Isle of Skye. They conclude that at least one of the marine-terminating glaciers draining the Younger Dryas Skye ice cap reworked earlier deposits and formed push moraines at its grounding line during a period of oscillatory retreat early in deglaciation. As yet, however, no published studies specifically describe De Geer moraines from mountainous areas of Scotland, despite the very likely occurence of such landforms in areas of high relief 
where separating or retreating ice margins flowed against reverse slopes and impounded meltwater (e.g. Borgström, 1979; Benn et al., 2003; Heyman \& Hättestrand, 2006).

Whilst some workers differ in their interpretations of De Geer moraine genesis, most are agreed on the general scale, context and morphology of these landforms (Table 1). Typically these moraines are less than $10 \mathrm{~m}$ high, a few tens of metres in width, and several hundreds of metres long. They form subaqueously at or near ice margins, and are aligned transverse to iceflow. Originally described by De Geer (1889), and named after him by Hoppe (1959), these features are also known as 'minor moraines' (Lee, 1959; Smith, 1982), 'washboard moraines' (Mawdsley, 1936), 'transverse eskers' (Virkkala, 1963) and 'cross-valley moraines' (Andrews \& Smithson, 1966; Heyman \& Hättestrand, 2006). Although the origin of De Geer moraines is widely debated, two main interpretations are favoured. One explanation for these linear, closely spaced moraines is that they formed subglacially in crevasses at the glacier bed, some distance behind a calving margin (Zilliacus, 1989). Surge advance of a glacier margin produces stresses parallel to the ice front, leading to the development of basal crevasses. Where the advanced margin is initially floating, subsequent settling of the crevassed glacier sole into unconsolidated sediment leads to bi-directional squeezing and infilling of the cavity. A variation on this interpretation is favoured by Sollid (1989) and Beaudry \& Prichonnet (1991), who invoke subglacial deposition from meltwater within the basal crevasses in preference to sediment squeezing to explain the glaciofluvial sediment within De Geer moraines in northern Norway and southeast Canada, respectively. Both mechanisms necessitate rapid lift-off and almost instanteous recession of the glacier in order to preserve these landforms and avoid any reworking during subsequent marginal oscillations.

Others have suggested a quite different mode of formation. This alternative model requires deposition of sorted sediments beyond the grounding line of a water-terminating glacier, and subsequent deformation of these sediments into transverse ridges by icemarginal advance (Larsen et al., 1991; Blake, 2000; Dix \& Duck, 2000; Lindén \& Möller, 2005). In this scenario, stacked sequences of fine-grained sediments are common, and diamicton units are interpreted as redeposited (water-lain) till, lodgement till, or subaqueous debris-flow deposits. Characteristically, De Geer moraines are seen to form at 
the grounding line of a glacier, whether the margin is a floating tongue, an overhanging cliff, or is completely grounded and only calving above the waterline. Few workers claim chronological inferences from De Geer moraines, as originally proposed (De Geer, 1889), but many accept that the accurate genetic interpretation of their sedimentary and geomorphological characteristics can be highly instructive with respect to understanding former glacier dynamics at retreating margins.

Here we describe a series of sedimentary exposures in the De Geer moraines of Glen Chaorach in the western Scottish Highlands, in order to better understand sedimentological processes and glacier dynamics at water-terminating margins. Exposed sections at nine localities are interpreted by comparing their constituent facies with those from other deglaciated environments. By coupling the sedimentology with architectures suggestive of glaciotectonic deformation, we present an allostratigraphic interpretation in which we make inferences with respect to the dynamics of the former outlet glacier during overall ice-cap recession. The resulting event chronology identifies three key stages of deglaciation - glacier separation, intra-lobe lake development with ice-margin fluctuation, and final lake drainage associated with deglaciation.

\section{Study area}

In the western Scottish Highlands climatic deterioration during the latter stages of the Windermere (Allerød) Interstadial (c. 14.5-12.9 ka BP) instigated the regrowth of an ice cap that extended $150 \mathrm{~km}$ from north to south and around $50 \mathrm{~km}$ from east to west (Sissons, 1980; Thorp, 1986; Ballantyne, 1997) (Fig. 1). The ice cap consisted of a major dome over Rannoch Moor feeding outlet glaciers south to Loch Lomond, west to Loch Awe, Loch Etive, and Glen Coe, north through Loch Ericht, and eastwards via Loch Rannoch, Glen Lyon and Glen Dochart (Thompson, 1972; Sissons, 1979; Horsfield, 1983; Thorp, 1986; Golledge, 2006, 2007). Separate icefields accumulated around the fringes of the main ice mass, and fed topographically constrained valley glaciers that deposited suites of 'hummocky moraine' and other ice-marginal landforms during their retreat (Bennett \& Boulton, 1993; Lukas, 2005; Benn \& Ballantyne, 2005; Bradwell, 2006; Finlayson, 2006).

FIGURE 1 
During the Younger Dryas glaciation a major eastward-flowing outlet glacier - the Dochart Glacier - drained a significant part of the main ice cap by connecting Strath Fillan to Loch Tay, where the glacier is thought to have terminated (Thompson, 1972; Sissons, 1979). Glen Chaorach is a south-trending tributary valley of Glen Dochart (Fig. 2), and during deglaciation it hosted an embayed marginal lobe of the Dochart Glacier. At its northern end, the valley is characterised by abundant morainic landforms, valley-side till cover, and spreads of glaciofluvial sand and gravel. Higher ground to the south has a somewhat sparser distribution of moraines, with thinner, less extensive till cover and with more widespread evidence of bedrock at or near surface.

\section{FIGURE 2}

\section{Geomorphology and context of exposures}

The landforms of Glen Chaorach are predominantly elongate ridges that trend obliquely across the axis of the valley from approximately southwest to northeast (Fig. 2). The ridges are linear or weakly curvilinear and are convex either up- or down-valley. They are typically less than $10 \mathrm{~m}$ high, 20 to $35 \mathrm{~m}$ wide, and up to $100 \mathrm{~m}$ in length. Inter-ridge spacing varies between 30 and $400 \mathrm{~m}$, and individual ridges are typically asymmetric with a steeper southern side (Table 1). In Glen Dochart, rounded mounds up to $20 \mathrm{~m}$ high and $150 \mathrm{~m}$ long rise above the present valley floor. These typically larger features are less elongate than those in Glen Chaorach. Between these two groups of mounds are terraces, the flat surfaces of which are locally punctuated with discrete rounded mounds up to $5 \mathrm{~m}$ high. Several large channels up to $500 \mathrm{~m}$ long incise the terraces, in many cases originating above the terraces on till or bedrock slopes, and in all cases descending to the northeast. Many of the higher slopes flanking Glen Chaorach are free of superficial deposits, and largely consist of approximately flat-lying metasedimentary bedrock. The rock is ice-scoured at elevations up to c. $550 \mathrm{~m}$, and hosts perched boulders in some areas (Fig. 2). At these higher levels, glacial meltwater has exploited structural weaknesses in the bedrock and incised northeast-trending channels up to c. $5 \mathrm{~m}$ deep.

The sedimentary sequences described here are all located in the lower, northern part of Glen Chaorach. The nine sections described were identified and logged during 
resurvey of the area by the British Geological Survey in 2006. All of the sections except NRG 216 and 213 occur within the cross-valley ridges described above. NRG 216 is cut into a terrace contiguous with one of these ridges, while NRG213 incises a considerably more extensive terrace at the confluence of Glen Chaorach and Glen Dochart. In addition to these key sections, a number of smaller or less well-exposed sections in stratified sediments were also noted (Fig. 2). Table 2 summarises the facies present and the basis for their interpretation, drawing on examples from both relict and active glaciofluvial, glaciolacustrine and glaciomarine environments. Figure 3 shows the stratigraphic relationships of these facies types at each of the nine key localities, in an approximately south to north sequence. An allostratigraphic approach, based on the recognition of distinct 'events' within a depositional sequence (Walker, 1990; Lønne, 1995), is used to infer the glaciodynamic episodes shown in Figure 3. These include periods of ice-margin advance or recession when variability in sediment input is likely to be at its greatest (Teller, 2003).

TABLE 2

FIGURE 3

\section{Sedimentological interpretation}

\section{Section NRG 212}

This exposure occurs on the side of the valley rather than the valley floor, at an elevation of approximately $310 \mathrm{~m}$. The massive to weakly laminated silt and sand (Facies 10/11) at the base of the exposed sequence (Fig. 3 A) was probably deposited relatively rapidly, perhaps from repeated hyperconcentrated flows that partially liquified previous flow deposits and dropped isolated 'floating' clasts. This requires subaqueous rather than subaerial deposition and suggests a minimum water level at the altitude of deposition (c. $310 \mathrm{~m}$ a.s.l. (above sea level)). The fine grain-size of the material may indicate a long transport path and deposition some distance from the glacier margin, or may simply be a function of sediment availability. Rhythmic deposition of overlying sorted gravel (Facies 5) represents a shift to a more episodic depositional environment (or at least a less turbulent water column), whilst the coarser grain size could reflect either more proximal deposition, or a switch in sediment supply. Basin muds (Facies 11) 
are succeeded by coarse-grained trough cross-bedded sand (Facies 9) and subsequently gravel (Facies 4); the sand was a product of higher-energy, channelised, transport, and the gravel was probably laid down by medium to high-density turbidity currents perhaps sourced from a subglacial meltwater conduit. Development on a fan surface of channels, such as indicated by the sediments described above, indicates (at least temporary) stabilisation of the fan / apron system.

Upward-coarsening throughout the section culminates in the diamicton that caps the sequence (Facies 2). The subangular and subrounded clasts in the deposit suggest derivation from subglacial sources (Benn \& Ballantyne, 1994), but the high variability of matrix composition and consolidation argues against it having been deposited subglacially, since such deposits are likely to be more-or-less homogeneous. Instead, this diamicton is interpreted as subglacial substrate that has been redeposited as a subaqueous debris flow. This inference is supported by the presence of lenses of laminated clay within the otherwise variable matrix, suggesting settling-out of suspended material between flow events. That the deposition of this diamicton was associated with an advance of the ice margin is further supported by the compressional deformation (thrusting) observed in the underlying sediments (Fig. 4A). Section NRG 212 therefore appears to preserve evidence of subaqueous deposition that initially occurred some distance from the glacier front, but was succeeded by more proximal sedimentation and ultimately by ice-contact glaciotectonism. There is no evidence (such as overconsolidation) that the sequence was overridden by the advancing ice, however.

\section{FIGURE 4}

\section{Section NRG 211}

The sequence at NRG 211 is shorter and shows more restricted facies variability (Fig. $3 \mathrm{~A}$ ). The lowest diamicton (Facies 2) lacks the degree of cohesion typical of subglacial tills and its friable sandy matrix is more consistent with emplacement by debris-flow processes, although no reverse-grading typical of debris-flow deposition is apparent. That it is overlain by poorly sorted gravel (Facies 4/5) suggests the later presence of meltwater, but it remains uncertain whether the diamicton was deposited subaerially or subaqueously. The weakly stratified gravel unit is indicative of a flow regime with suffi- 
ciently high-energy to entrain material of a coarse grade, and if deposited subaqueously, may have been emplaced by episodic high-density turbidity currents. The laminated silt and fine sand that overlie it (Facies 8) reflect subsequent non-turbulent conditions in which settling-out of suspended sediment occurred, probably in a subaqueous overbank environment beyond the margins of the main debris-flow channel. The degree of sorting of the sediments is consistent with transport to the ice margin as suspended load via subglacial meltwater conduits. The uppermost stratified diamicton (Facies 2) and the single large boulder at the top of the section probably relate to ice-proximal debris avalanches. In summary, NRG 211 can be interpreted as recording ice-marginal sedimentation most probably in a subaqueous environment dominated by input from emerging subglacial streams, and punctuated by periodic avalanching of unsorted sediments from the glacier margin.

\section{Section NRG 216}

This section is characterised by facies bounded by conformable planar contacts with numerous abrupt changes in grain size (Fig. 3 A). The poorly sorted gravel (Facies 4) at the base of the section was probably deposited from high-density turbidity currents forming a subaqueous fan or apron (Table 2). That it does not grade into the overlying silt and sand (Facies 8), however, suggests that the two units represent separate depositional events, and not different stages of a single event. The higher energy flow required to transport the gravel may have arisen during periods of seasonal melt when subglacial water volume and glaciohydrostatic pressure was high. The abrupt switch to rhythmic sedimentation of silt and sand suggests a period of lower-energy flow, perhaps as a result of decreased melt or, given the likely fan or apron-type environment, as a result of channel-switching that directed the dominant meltwater input elsewhere. Similar stratigraphic relationships are evident throughout the sequence, and together give an impression of a highly variable sedimentation regime perhaps controlled by meltwater and sediment supply routes and by their seasonal fluctuations. The trough cross-bedded sand unit (Facies 9) indicates that at least some of this sediment and meltwater input took place in migrating channels, which is consistent with a palaeo-fan / apron environment. 
of the exposure the silt and sand (Facies 8) is cut by gravel-filled fractures (Facies 4). Large blocks of silt and sand within the gravel are plastically deformed, with the geometry of the deformation structures being consistent with the downward injection of the fluidised gravel (van der Meer et al., 1999) (Fig. 4 B). This is interpreted to have occurred as a result of loading (either by increasing water depth or rapidly accumulating sediment) and increasing pore-water pressure in the overlying gravel. Higher in the section a bedded sand unit (Facies 9) at approximately $0.8 \mathrm{~m}$ depth is intruded by a dyke of massive silt, also interpreted as indicative of high pore-water pressure that in this case led to sediment liquefaction, fluidisation and hydrofracturing. Normal and reverse faults in the sand unit, in some instances forming conjugate pairs, provide further evidence of loading-induced deformation (Fig. 4C). Thus the overall sequence seems to reflect variable sedimentation, under abruptly changing conditions, that was accompanied by loading-induced synsedimentary deformation, the latter perhaps reflecting high sedimentation rates. The location of this section in the valley bottom (Fig. 2) is consistent with these sediments having been laid down on the floor of a former lake.

\section{Section NRG 222}

Massive silt and sand (Facies 7/10) at the base of NRG 222 (Fig. 3 A) suggests rapid deposition from hyperconcentrated flows, probably as underflow turbidity currents (Table 2). A high-density turbidity current carrying gravel and coarse sand (Facies 4/5) eroded into the massive sand unit, suggesting that the gravel was transported by channelised rather than sheet flow. The graded diamicton (Facies 2/8/11) above this unit fines upwards and reflects the gradual settling out of suspended sediment following initial input of a poorly sorted sediment mass. This may have occurred in a channel under waning flow conditions. Continued input of silt and sand (Facies 8/11) which settled in non-turbulent or distal water produced the laminated unit in the middle of the section, and was initially followed by periodic input of variably well-sorted coarsergrained sediments (Facies 4/5/7/9) and later by renewed hyperconcentrated flows that laid down the uppermost massive silt and sand unit (Facies 7/9/10).

The section exhibits lateral variability in the sedimentary sequence, with greatest facies variation occuring at the western end (Fig. 4 E). The complex architecture of the units in this part of the section, and the orientation of the exposure perpendicular to 
the valley axis, presents difficulties in genetic interpretation, but a few possibilities may be proposed. The interdigitating relationship of the silt and sand (Facies 8/11) with gravel and diamicton (Facies 2) may be the result of liquefaction and intrusion of the latter into the finer-grained substrate. This could have occurred under self-weight and hydrostatic stresses (static loading) or as a result of glacier advance and the propagation of stress through proximal sediments. Normal and reverse faulting of bedded sand (Facies 8) in the section may lend some support to these proposals. Alternatively, the irregular contacts between facies may be the result of glacier-induced shearing along a plane normal to the face, brought about by compression of the sediment as the ice margin advanced. A third possibility is that this part of the section slumped at some stage, and the interfingering facies are the result of post-depositional deformation. This may have taken place following recession of the ice margin when support for the sediment pile was removed. The final consideration is that the architecture could reflect primary sedimentation variabilities, that is, localised and abrupt switching in sediment supply and deposition. Whilst all four may have played a role to some extent, the interpretation favoured here involves a combination of loading, liquification and slumping, on the basis that the contacts between facies do not appear to be either primary sedimentary features or the result of compressional glaciotectonism. These uncertainties aside, it is clear that the sediments represented in section NRG 222 reflect glaciolacustrine deposition of sediments sourced from both glaciofluvial and ice marginal environments.

\section{Section NRG 221}

The section NRG 221 lies close to, and perpendicular to, NRG 222, but occurs within a different cross-valley ridge. The majority of the section is dominated by bedded sand units (Facies 8), with minor laminated silt (Facies 11) and beds of massive gravel (Facies 4 ) (Fig. 3 B). The reverse-graded diamicton (Facies $1 / 2 / 5$ ) that caps the sequence is silty and cohesive near the top, and resembles a submarginal till possibly originating as a debris flow deposit but subsequently compacted. The most striking features of the exposure, however, are the deformation structures in the sediments (Fig. 5). The gross structure is a broad southward-verging asymmetric open or overturned fold, cut by south-directed thrusts indicating that folding preceded thrusting (but not necessarily in a separate event). Folded bedding is clearly visible in the sand (Facies 8/9), and to a lesser extent in the laminated silt (Facies 11). This ductile deformation occurs 
in close association with brittle deformation in the form of thrusts and minor reverse faults. The largest thrust can be traced laterally for approximately $3.5 \mathrm{~m}$ and offsets the bedding within the sands and silts by up to $0.25 \mathrm{~m}$ (Fig. 5). Gravel (Facies 4) infills this discontinuity, and thickens in the central part of the section and towards the south. Smaller structures are present in the section, notably disruptions to bedding in the sand and silt units. The silt and sand dykes that punctuate, but do not offset the bedding, are interpreted as water-escape features, in which sediments with high water content were fluidised and remobilised. Their high pore pressures first led to hydrofracturing of the surrounding substrate, and subsequently to infilling of the discontinuities when pore-water pressures subsided. This evidence of saturated sediments lends further support to their being deposited subaqueously. That the water-escape features cross-cut the folded beds suggests that they formed after the episode of compressional deformation.

\section{FIGURE 5}

On the basis of the deformation architecture exhibited by the sediments exposed in this section, the following scenario can be proposed. Initial glaciolacustrine and/or glaciofluvial sedimentation that deposited the interbedded silt, sand and gravel sequence (Facies $4 / 8 / 9 / 11$ ) was succeeded by a period of lateral compression that produced the open folding seen in the sediments. Continued lateral stress led to the development of thrusts and an increase in pore-water pressure in the gravel unit. Hydrofracturing of the confining strata then occurred and water-escape took place, remobilising sediment and subsequently infilling the discontinuities (thrusts). The most likely mechanism to produce this sequence of events is the steady advance of the Dochart Glacier, from which avalanching debris (Facies 6) and deposition of submarginal till (Facies 1/2) produced the uppermost diamicton (Fig. 6).

\section{FIGURE 6}

\section{Section NRG 220}

NRG 220 exposes an overall coarsening-upward succession of silt, sand, gravel and diamicton in a cross-valley ridge (Fig. $3 \mathrm{~B}$ ). The silt at the base of the exposure is 
massive and very firm (Facies 10) and has a convolute contact with the overlying sand (Facies 7) (Fig. 4F). The lack of lamination or bedding in the silt suggests that it may have been deposited rapidly, perhaps from a hyperconcentrated flow (Table 2), and was subsequently loaded prior to dewatering to produce partial liquefaction and convolutions interpreted as flame structures that intrude the overlying sediments. As with NRG 221, the evidence of liquefaction suggests high porewater contents consistent with subaquaeous conditions. The gravel unit (Facies 4) suggests higher energy meltwater deposition, perhaps in the form of turbidity currents, and is succeeded by a sandy diamicton (Facies 1/2) at the top of the sequence. It is likely that this sequence represents the encroachment of an ice margin into a glaciolacustrine sediment pile, producing stresses sufficient to engender liquefaction and bringing unsorted ice-marginal debris into the sequence. Normal faulting in the sand unit may have resulted from slumping on the ice-distal side of the moraine.

\section{Section NRG 219}

Near the confluence of Glen Chaorach with Glen Dochart, the tributary valley widens and section NRG 219 exposes sediments in a cross-valley ridge. Laminated silt (Facies 11) at the base of the sequence reflects suspension settling in non-turbulent water, which was followed by episodic but sustained input of gravel (Facies 8/9), possibly via debris flows from an emerging subglacial stream. This sequence of gravel overlying laminated silt is repeated throughout the rest of the section, indicative of abrupt changes in sedimentation style (Fig. 3 B). This may have been the result of possibly seasonal fluctuations in meltwater flux, or may reflect channel switching within the glaciofluvial / glaciolacustrine system. None of the sediments show evidence of deformation, although the upper silt units are very firm and may have been subjected to high overburden pressures. Overall, the sedimentary sequence at this locality represents a relatively stable ice-marginal glaciolacustrine setting in which periodic high-discharge events punctuated background sedimentation.

\section{Section NRG 218}

Alternating units of sand (Facies 8/9/11) and gravel (Facies 4/5) in NRG 218 attest to variations in transport capacity of the glaciofluvial or glaciolacustrine system that deposited them. An overall sense of normal grading dominates the sequence, and only 
where coarser sediments overlie finer-grained material do erosional contacts occur (Fig. $3 \mathrm{~B})$. The poor sorting of each sediment unit suggests a turbulent or short transport path, and may be reflective of a debris-flow origin from emerging subglacial streams. Despite the sediments forming an elongate cross-valley ridge, suggesting ice-contact formation, no evidence of glaciotectonism is apparent. The sequence is therefore best interpreted as reflecting ice-marginal sedimentation at a stable or receding margin.

\section{Section NRG 213}

The short section exposed at NRG 213 is composed of well-sorted, bedded sediments (Fig. 3 B) that form a flat extensive terrace at the mouth of Glen Chaorach. The basal gravel (Facies 4) is well-sorted and has little sand in its matrix, consistent with prolonged, relatively high-energy fluvial transport. Suspension settling in a glaciolacustrine environment laid down the overlying silt (Facies 11), which is succeeded by coarsening units of sand (Facies 8). One of these sand units is cross-bedded and reflects flow to the southeast, probably in a fan or channel environment. The uppermost unit is poorly sorted gravel (Facies 4) that may have been deposited in a highly turbulent fluvial environment, or as a high-density turbidity current in a glaciolacustrine setting. That the sequence composes part of an extensive terrace suggests that the sediments may best be interpreted as products of glaciofluvial deposition, probably laid down in a sub-aerial ice-proximal environment.

\section{Discussion}

Sediment is supplied to glacier margins predominantly by two key mechanisms subglacial deformation of unconsolidated unsorted material (till), and meltwater transport either through or on the ice that delivers sorted sediments in suspension and as traction bed-loads (Edwards, 1986; Lønne, 1995; Benn \& Evans, 1998). The dominance of sorted and bedded or laminated sediments over unsorted diamictons in all of the Glen Chaorach sections provides convincing evidence that deposition from glacial meltwater was particularly important, probably in a glaciolacustrine or glaciofluvial setting. This was brought about by separation of a major outlet lobe of the Younger Dryas ice cap that drained eastward along Glen Dochart (Golledge, 2007) from a mountain icefield to the south. Sedimentary evidence at NRG 212 suggests a former water level at around 
$310 \mathrm{~m}$ a.s.l., and since the valley floor below this site lies at $250 \mathrm{~m}$ a.s.l. it is likely that, at its maximum, the depth of the former lake was c. $50-60 \mathrm{~m}$. The lake most probably drained and refilled throughout its life, as is known to have occurred in former glacial lakes elsewhere in Scotland (Ballantyne, 1979; Brazier et al., 1998), possibly as ice-marginal crevasses and subglacial conduits either opened or closed.

The exposed sediments commonly exhibit abrupt, but not necessarily erosional contacts, and reflect a highly variable sedimentary environment. Laminated sediments indicative of suspension settling under non-turbulent conditions are often juxtaposed with poorly sorted coarse gravel units typical of high-density turbidity currents or unsorted diamictons more commonly associated with ice-proximal avalanching of suband supraglacial material (Fig. 6). Blake (2000) suggests that compositional variation within De Geer moraines may be related to the location of outlets of subglacial streams, a notion that echoes earlier sedimentary investigations of ice-contact submarine fans (Lønne, 1995). Others suggest that advection of subglacial sediments towards the ice margin, and their intercalation with glaciofluvial canal-infill sediments, forms the proximal part of subaqueous moraines, and that more distal sediments are deposited by prograding sediment gravity-flows that interfinger with glaciolacustrine deposits (Benn, 1996; Lindén \& Möller, 2005). Since clastic sedimentary sections are thought to be reliable archives of 'short-lived internally controlled events' (Fard, 2001, : p145), whether climatically induced or not, both scenarios may help to explain the localised nature of the sedimentary record produced in such environments, and the facies variability seen in the Glen Chaorach examples described here.

Where glaciotectonic deformation occurs in these examples, it is always uni-directional (south-vergent) and provides evidence of ice-marginal oscillations after accumulation of the sediment pile. The presence of both brittle and ductile deformation features is common in sediments found at ice margins (Benn \& Evans, 1998; Menzies, 2000; Golledge, 2002; Phillips et al., 2002), and results from the propagation of glacier-induced stresses through the glacier bed. The glacier advances associated with sediment deformation and deposition of diamictons appear to have been the final events. This may indicate that whilst marginal advance was relatively slow, its recession was probably more rapid. This is typical of water-terminating margins that lose the majority of their mass through calving (Paterson, 1994), particularly where glacier thinning occurs (van der 
Veen, 1996). Since none of the recorded sedimentary sequences is capped by drapes of glaciolacustrine silt and clay commonly associated with widespread suspension settling, it may be speculated that the majority of sediment delivery into the glacial lake was as focussed underflows rather than as diffuse plumes, probably governed by the locations of emerging subglacial meltwater conduits.

\section{Event chronology}

During the Younger Dryas glacial episode, Glen Chaorach was occupied by ice from two confluent glaciers (Fig. 7, A). Northward ice flow from the Ben More glacier contributed to the much larger, eastward-flowing Dochart glacier, which acted as one of the principal southern outlets of the ice cap centred over Rannoch Moor (Fig. 1). Thinning of these glaciers during the initial stages of deglaciation led to the creation of an intralobe lake, and deposition of laminated and bedded fine-grained sediments. Continued separation of the glaciers was accompanied by an increase in the area and depth of the ice-dammed lake, and by changes in the flow pattern of the two ice masses (Fig. 7, B). Southward-directed deformation structures preserved in the lake sediments indicate that during this phase, minor oscillations of the Dochart Glacier formed De Geer moraines by tectonising glaciolacustrine sediments at successive grounding lines (Fig. 7, B). The locations of such grounding lines were probably governed by high points on the valley floor, such as bedrock knolls, that acted as 'pinning points'. Further deglaciation following this period of stability led to recession of the ice margin towards Glen Dochart until Glen Chaorach became ice free, eventually removing the dam that had previously impounded supraglacial and subglacial meltwater. Consequently, an ice-marginal, subaerial glaciofluvial environment was established in which the extensive, channelled terraces composed of bedded, well-sorted sediments were formed (Fig. $7, \mathrm{C})$. Subsequent retreat of the glacier front formed the large morainic mounds in Glen Dochart (Fig. 2), prior to final disappearance of the ice sometime after $11.6 \mathrm{ka} \pm 1.0$ ka BP (Golledge et al., 2007).

\section{FIGURE 7}

\section{Conclusions}

Geological and geomorphological mapping has identified a population of elongate lin- 
ear cross-valley ridges in Glen Chaorach, a tributary valley of the much larger Glen Dochart. During the Younger Dryas, Glen Dochart accomodated a major outlet glacier of the west Highland ice cap, formerly centred over Rannoch Moor, and Glen Chaorach was filled with confluent ice sourced on the east side of Ben More. After initially feeding ice into the main glacier, the tributary valley glacier thinned and the two ice masses separated. Moraines formed in Glen Chaorach as the glaciers retreated, and meltwaters accumulated to form an ice-dammed lake. Sedimentary characteristics of the moraines, together with their geomorphology and context, strongly suggest that they formed at the grounding line of a water-terminating glacier margin that occupied a quasi-stable position in the valley during intial deglaciation. Sediments were deposited in the ice-marginal lake primarily through focussed delivery in subglacial conduits and from ice-front debris-flows. Oscillations of the glacier margin led to deformation of the sediment pile but were followed by rapid recession to pinning points lower in the valley. When glacier thinning had proceeded to the extent where an ice dam could no longer confine meltwater in Glen Chaorach, ice-marginal glaciofluvial sedimentation ensued, followed by frontal retreat of the Dochart Glacier.

\section{Acknowledgements}

This research was carried out as part of the 'Grampian Highlands' mapping project of the British Geological Survey during 2006/7. The work benefited significantly from useful discussions with David Sugden and numerous BGS colleagues both in the field and elsewhere. We are grateful to Tom Bradwell, Richard Smith, Per Möller, two anonymous referees and the Editor for constructive comments on the manuscript. The paper is published with the permission of the Executive Director of the British Geological Survey, NERC. 


\section{References}

Andrews, J.T, \& Smithson, B.B. 1966. Till fabrics of the cross-valley moraines of north-central Baffin Island, Northwest Territories, Canada. Geological Society of America Bulletin, 77, 271-290.

Ballantyne, C. K. 1979. A sequence of Lateglacial ice-dammed lakes in East Argyll. Scottish Journal of Geology, 15, 153-160.

Ballantyne, C. K. 1997. The periglacial geomorphology of Scotland. Pages 166-178 of: Gordon, J. E. (ed), Reflections on the Ice Age in Scotland: an Update on Quaternary Studies. Glasgow: Scottish Association of Geography Teachers and Scottish Natural Heritage.

Beaudry, L. M., \& Prichonnet, G. 1991. Late Glacial De-Geer moraines with glaciofluvial sediment in the Chapais area, Québec (Canada). Boreas, 20, 377-394.

Benn, D. I. 1996. Subglacial and subaqueous processes near a glacier grounding line: Sedimentological evidence from a former ice-dammed lake, Achnasheen Scotland. Boreas, 25, $23-36$.

Benn, D. I., \& Ballantyne, C. K. 1994. Reconstructing the transport history of glaciogenic sediments - A new approach based on the co-variance of clast form indexes. Sedimentary Geology, 91, 215-227.

Benn, D. I., \& Ballantyne, C. K. 2005. Palaeoclimatic reconstruction from Loch Lomond Readvance glaciers in the West Drumochter Hills, Scotland. Journal of Quaternary Science, 20, $577-592$.

Benn, D. I., Kirkbride, M. P., Owen, L. A., \& Brazier, V. 2003. Glaciated valley landsystems. Pages 372-406 of: Evans, D.J.A. (ed), Glacial Landsystems. London: Arnold.

Benn, D. I., Hulton, N. R. J., \& Mottram, R. H. 2007a. 'Calving laws', 'sliding laws' and the stability of tidewater glaciers. Annals of Glaciology, 46, 123-130.

Benn, D. I., Warren, C. R., \& Mottram, R. H. 2007b. Calving processes and the dynamics of calving glaciers. Earth-Science Reviews, 82, 143-179.

Benn, D.I., \& Evans, D.J.A. 1998. Glaciers and Glaciation. London: Arnold.

Bennett, M.R., \& Boulton, G.S. 1993. Deglaciation of the Younger Dryas or Loch Lomond Stadial ice-field in the northern Highlands, Scotland. Journal of Quaternary Science, 8, $133-145$.

Blake, K. P. 2000. Common origin for De Geer moraines of variable composition in Raudvassdalen, northern Norway. Journal of Quaternary Science, 15, 633-644. 
Borgström, I. 1979. De Geer moraines in a Swedish mountain area? Geografiska Annaler, 61(1-2), 35-42.

Bradwell, T. 2006. The Loch Lomond Stadial glaciation in Assynt: a reappraisal. Scottish Geographical Journal, 122, 274-292.

Brazier, V., Kirkbride, M. P., \& Gordon, J. E. 1998. Active ice-sheet deglaciation and icedammed lakes in the northern Cairngorm Mountains, Scotland. Boreas, 27(4), 297-310.

De Geer, G. 1889. Ändmoräner i trakten mellan Spånga och Sundbyberg. Geologiska Föreningens i Stockholm Förhandlingar, 11, 395-397.

Dix, J. K., \& Duck, R. W. 2000. A high-resolution seismic stratigraphy from a Scottish sea loch and its implications for Loch Lomond Stadial deglaciation. Journal Of Quaternary Science, 15(6), 645-656.

Edwards, M. 1986. Glacial Environments. Pages 445-470 of: Reading, H.G. (ed), Sedimentary Environments and Facies, second edn. Oxford: Blackwell.

Eyles, N., \& Miall, A. D. 1984. Glacial facies. Pages 15-38 of: Walker, R.G. (ed), Facies Models. Geoscience Canada Reprint Series, no. 1. Geological Association of Canada.

Eyles, N., Miall, A. D., \& Eyles, C. H. 1984. Lithofacies types and vertical profile models - an alternative approach to the description and environmental interpretation of glacial diamict and diamictite sequences - Reply. Sedimentology, 31(6), 891-898.

Fard, A. M. 2001. Morphology of subglacial conduit deposits: control by bedrock topography, discharge flow variation, or both? A cautionary case study: Axelsberg, Nynäshamn, south central Sweden. Global and Planetary Change, 28, 145-161.

Finlayson, A.G. 2006. Glacial geomorphology of the Creag Meagaidh Massif, western Grampian Highlands: implications for local glaciation and palaeoclimate during the Loch Lomond Stadial. Scottish Geographical Journal, 122, 293-307.

Golledge, N. 2002. Glaci-tectonic deformation of proglacial lake sediments in the Cairngorm Mountains. Scottish Journal of Geology, 38, 127-136.

Golledge, N. R. 2006. The Loch Lomond Stadial glaciation south of Rannoch Moor: new evidence and palaeoglaciological insights. Scottish Geographical Journal, 122, 326-343.

Golledge, N. R. 2007. An ice cap landsystem for palaeoglaciological reconstructions: characterizing the Younger Dryas in western Scotland. Quaternary Science Reviews, 26, 213-229. 
Golledge, N. R., Fabel, D., Everest, J. D., Freeman, S., \& Binnie, S. 2007. First cosmogenic ${ }^{10} \mathrm{Be}$ age constraint on the timing of Younger Dryas glaciation and ice cap thickness, western Scottish Highlands. Journal of Quaternary Science, 22, 785-791.

Heyman, J., \& Hättestrand, C. 2006. Morphology, distribution and formation of relict marginal moraines in the Swedish Mountains. Geografiska Annaler, 88A, 253-265.

Hoppe, G. 1959. Glacial morphology and inland ice recession in northern Sweden. Geografiska Annaler, 41, 193-212.

Horsfield, B.R. 1983. The deglaciation pattern of the Western Grampians of Scotland. Unpublished Ph.D thesis, University of East Anglia.

Larsen, E., Longva, O., \& Follestad, B. A. 1991. Formation of De Geer moraines and implications for deglaciation dynamics. Journal of Quaternary Science, 6, 263-277.

Lee, H.A. 1959. Surficial geology of southern District of Keewatin and the Keewatin ice divide, Northwest Territories. Vol. 51. Bulletin of the Canadian Geological Survey.

Lindén, M., \& Möller, P. 2005. Marginal formation of De Geer moraines and their implications to the dynamics of grounding-line recession. Journal of Quaternary Science, 20, 113-133.

Lønne, I. 1995. Sedimentary facies and depositional architecture of ice-contact glaciomarine systems. Sedimentary Geology, 98, 13-43.

Lukas, S. 2005. A test of the englacial thrusting hypothesis of 'hummocky' moraine formation: case studies from the northwest Highlands, Scotland. Boreas, 34, 287-307.

Mawdsley, J.B. 1936. Wash-board moraines of the Opawica-Chibougamau area, Quebec. Transactions of the Royal Society of Canada, 30, 9-12.

Menzies, J. 2000. Micromorphological analyses of microfabrics and microstructures indicative of deformation processes in glacial sediments. Pages 245-257 of: Maltman, A. J., Hubbard, B., \& Hambrey, M. J. (eds), Deformation of Glacial Materials. London: The Geological Society.

Paterson, W.S.B. 1994. The Physics of Glaciers. 3rd edn. Oxford: Pergamon.

Peck, V. L., Hall, I. R., Zahn, R., Grousset, F., Hemming, S. R., \& Scourse, J. D. 2007. The relationship of Heinrich events and their European precursors over the past 60 ka BP: a multi-proxy ice-rafted debris provenance study in the North East Atlantic. Quaternary Science Reviews, 26, 862-875. 
Phillips, E. R., Evans, D. J. A., \& Auton, C. A. 2002. Polyphase deformation at an oscillating ice margin following the Loch Lomond Readvance, central Scotland, UK. Sedimentary Geology, 149, 157-182.

Reeh, N. 1968. On the calving of ice from floating glaciers and ice shelves. Journal of Glaciology, 7, 215-232.

Rignot, E., \& Kanagaratnam, P. 2006. Changes in the velocity structure of the Greenland Ice Sheet. Science, 311, 986-990.

Sissons, J.B. 1979. The Loch Lomond Stadial in the British Isles. Nature, 280, 199-203.

Sissons, J.B. 1980. Palaeoclimatic inferences from Loch Lomond Advance glaciers. Pages 31-43 of: Lowe, J. J., Gray, J. M., \& Robinson, J. E. (eds), Studies in the Lateglacial of North-west Europe. Oxford: Pergamon.

Smith, G. W. 1982. End moraines and the pattern of last retreat from central and south coastal Maine. Pages 195-209 of: Larson, G. J., \& Stone, B.D. (eds), Late Wisconsinan Glaciation of New England. Dubuque, Iowa: Kendall-Hunt.

Sollid, J. L. 1989. Comments on the genesis of De Geer moraines. Norsk Geografisk Tidsskrift, 43, 45-47.

Teller, J. T. 2003. Subaquatic landsystems: large proglacial lakes. Pages 348-371 of: Evans, D.J.A. (ed), Glacial Landsystems. London: Arnold.

Thompson, K.S.R. 1972. The last glaciers of Western Perthshire. Unpublished Ph.D thesis, University of Edinburgh.

Thorp, P.W. 1986. A mountain icefield of Loch Lomond Stadial age, western Grampians, Scotland. Boreas, 15, 83-97.

van der Meer, J. J. M., Kjær, K. H., \& Krüger, J. 1999. Subglacial water-escape structures and till structures, Sléttjökull, Iceland. Journal of Quaternary Science, 14, 191-205.

van der Veen, C.J. 1996. Tidewater calving. Journal of Glaciology, 42, 375-385.

Virkkala, K. 1963. On ice-marginal features in southwestern Finland. Bulletin de la Commission géologique de Finlande, 210, 1-76.

Walker, R.G. 1990. Facies modelling and sequence stratigraphy. Journal of Sedimentary Research, 60, 777-786.

Zilliacus, H. 1989. Genesis of De Geer moraines in Finland. Sedimentary Geology, 62, 309-317. 


\section{Figure and Table captions}

Table 1: Characteristics of De Geer moraines from published examples, as well as data from the features described in this study.

Table 2: Facies interpretation for the range of sediments recorded in Glen Chaorach, based on examples from both presently and formerly glaciated areas.

Figure 1: The location of the study area in a Scottish context, and in relation to the extent of Younger Dryas glaciation (shaded area) in the western Highlands (from various sources). Note the position of the site at the margin of a key eastward-draining outlet glacier. Abbreviations: GD - Glen Dochart, LL - Loch Lomond, LA - Loch Awe, LE - Loch Etive, GC - Glen Coe, LEr - Loch Ericht, LR - Loch Rannoch, GL - Glen Lyon, SF - Strath Fillan.

Figure 2: The physiography and simplified geology of Glen Chaorach and its confluence with Glen Dochart, showing the positions of numbered locations described in the text and other localities where sediments were observed. Topographic contours are at $10 \mathrm{~m}$ vertical interval, derived from Ordnance Survey Profile data, (C) Crown Copyright

Figure 3: Scaled sedimentological logs illustrating vertical sections through the nine exposures described in this study, presented in order as described in the text. The logs show key facies types and the nature of bounding contacts, and are only generalised where units exhibit high lateral variability in thickness and / or character. The composition of each unit, their stratigraphic relationships, and the nature of their upper and lower contacts provide the basis of the genetic interpretations and allostratigraphic significance. Facies codes from Eyles \& Miall (1984); Eyles et al. (1984).

Figure 4: Examples of facies types from some of the sections described. A: Bedded sand and gravel exhibiting southeasterly directed thrusts and minor folding, NRG 212. B: Laminated and bedded silt and sand unit disrupted by hydrofracturing, NRG 216. C: Faulted trough-cross-bedded and planar-bedded sand intruded by a massive silt dyke, NRG 216. D: Conformable planar sequence of massive sand overlain by thin diamicton and laminated silt, NRG 216. E: Complex intercalation of sorted and bedded sediments with unsorted gravel diamicton units, NRG 222. F: Flame structures in silt intruding into overlying sand, NRG 220 . 
Figure 5: Field photograph of the folded, sorted sediments described at NRG 221, and tracing of principal facies and their structures. Note 1) the close association of ductile deformation (folding), with brittle deformation (fractures and thrusts), and 2) bed-thickening in the lower limb of the folded and fluidised gravel unit.

Figure 6: Schematic illustration of the ice-marginal environment thought to have existed in Glen Chaorach during Younger Dryas deglaciation. Sediment input to the ice-dammed lake occurred 1) through debris flows from emerging englacial debris bands, 2) via subglacial meltwater conduits, 3) from iceberg rainout, and 4) as submarginal till. Oscillation of the glacier at the grounding line tectonised the adjacent sediment pile and generated the transverse ridges interpreted as De Geer moraines. Not to scale.

Figure 7: Key stages in ice-margin evolution during deglaciation of the study area. A: Glen Chaorach is filled by confluent ice of the Dochart and Ben More glaciers. Thinning leads to separation of the ice masses which leads to early development of an ice-dammed lake and deposition of fine-grained sediments. B: continued recession produces a lake deep enough to enable calving of the grounded glacier, and the margin is stable enough to oscillate at its grounding line and thereby form De Geer moraines. C: During the final stages of ice-marginal ponding, the confining glacier no longer oscillates or tectonises the sediments, and ultimately thins to the mouth of Glen Chaorach enabling free marginal drainage that gives rise to subaerial glaciofluvial deposition. Topographic contours are at $10 \mathrm{~m}$ vertical intervals, derived from Ordnance Survey Profile data, (C) Crown Copyright 


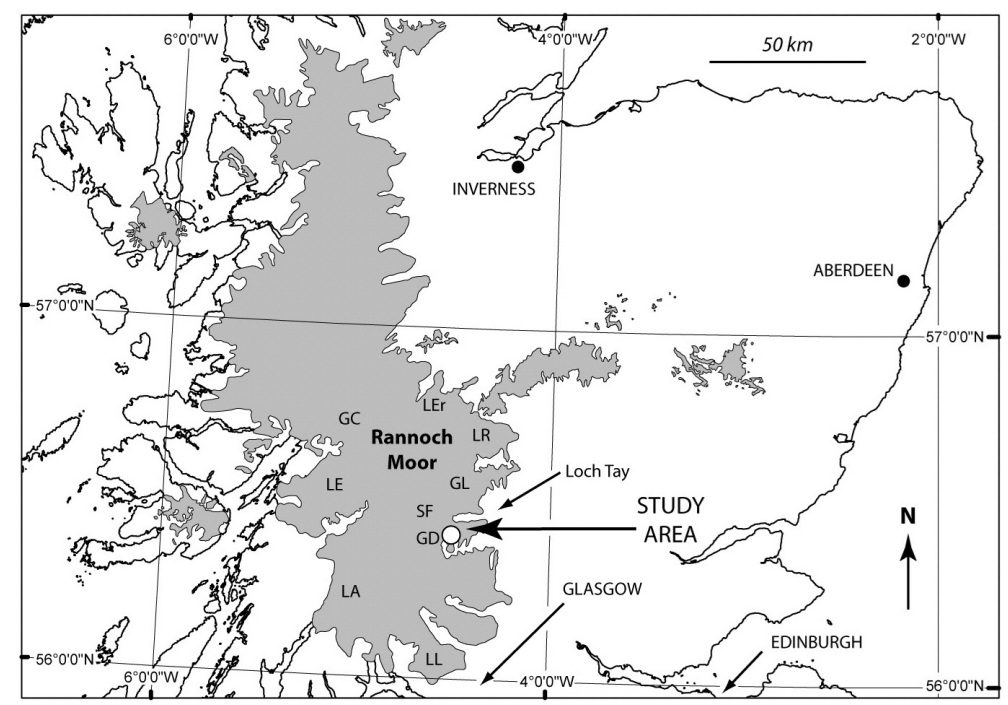

Figure 1: 
Table 1:

\begin{tabular}{|c|c|c|c|c|c|c|c|c|c|}
\hline Study site & Orientation & $\begin{array}{l}\text { Scale } \\
\text { Height }\end{array}$ & Width & Length & Spacing & Slope & $\begin{array}{l}\text { Facies \& } \\
\text { architecture }\end{array}$ & Interpretation & Reference \\
\hline $\begin{array}{l}\text { Glen } \\
\text { Chaorach, } \\
\text { western } \\
\text { Scottish } \\
\text { Highlands }\end{array}$ & $\begin{array}{l}\text { Broadly } \\
\text { perpendicular to } \\
\text { valley axis and } \\
\text { presumed ice } \\
\text { flow }\end{array}$ & $<10 \mathrm{~m}$ & $20-35 m$ & $50-100 m$ & $30-400 m$ & $\begin{array}{l}\text { Asymmetric, } \\
\text { steeper distal } \\
\text { slope }\end{array}$ & $\begin{array}{l}\text { Diamicton, silt, } \\
\text { sand and gravel; } \\
\text { intercalated, } \\
\text { stratified, folded, } \\
\text { thrust }\end{array}$ & $\begin{array}{l}\text { Ice-marginal } \\
\text { subaqeous debris } \\
\text { flows, lake floor } \\
\text { deposits, } \\
\text { deformation by } \\
\text { oscillating ice margin }\end{array}$ & This study \\
\hline $\begin{array}{l}\text { Raudvassdalen } \\
\text { Northern } \\
\text { Norway }\end{array}$ & $\begin{array}{l}\text { Perpendicular to } \\
\text { ice flow; oblique } \\
\text { to valley slope }\end{array}$ & $0.5-5 \mathrm{~m}$ & $1-30 m$ & $<300 m$ & $\begin{array}{l}25-240 \mathrm{~m}, \\
\text { av. } 86 \mathrm{~m}\end{array}$ & $\begin{array}{l}\text { Symmetrical, } \\
\text { 20deg, some } \\
\text { slightly steeper } \\
\text { down-ice }\end{array}$ & $\begin{array}{l}\text { Till, glaciofluvial } \\
\text { sediments, } \\
\text { marine } \\
\text { sediments; } \\
\text { folded, stacked, } \\
\text { deformed }\end{array}$ & $\begin{array}{l}\text { Overridden } \\
\text { grounding line } \\
\text { deposits }\end{array}$ & Blake (2000) \\
\hline $\begin{array}{l}\text { Norrbotten, } \\
\text { Northern } \\
\text { Sweden }\end{array}$ & $\begin{array}{l}\text { Transverse to } \\
\text { iceflow, upflow } \\
\text { concave in } \\
\text { topographic } \\
\text { lows, convex on } \\
\text { elevated ground }\end{array}$ & $1-3 m$ & av. $30 \mathrm{~m}$ & $\begin{array}{l}100 \mathrm{~m}- \\
3 \mathrm{~km}\end{array}$ & $50-200 m$ & $\begin{array}{l}\text { Asymmetric, } \\
\text { steeper distal } \\
\text { slope }\end{array}$ & $\begin{array}{l}\text { Diamictons, silt, } \\
\text { sand, gravel and } \\
\text { cobbles; } \\
\text { stratified, } \\
\text { interfingered, } \\
\text { stacked, folded, } \\
\text { thrust }\end{array}$ & $\begin{array}{l}\text { Intercalated } \\
\text { deforming bed } \\
\text { diamictons and } \\
\text { glaciofluvial canal- } \\
\text { infill sediments, syn- } \\
\text { and post-depositional } \\
\text { deformation, distal } \\
\text { slope prograding } \\
\text { sediment gravity } \\
\text { flows }\end{array}$ & $\begin{array}{l}\text { Linden \& } \\
\text { Moller } \\
\text { (2005) }\end{array}$ \\
\hline $\begin{array}{l}\text { Loch Ainort, } \\
\text { western } \\
\text { Scotland }\end{array}$ & $\begin{array}{l}\text { Perpendicular to } \\
\text { valley axis and } \\
\text { presumed ice } \\
\text { flow }\end{array}$ & $\begin{array}{l}0.2- \\
12 \mathrm{~m}\end{array}$ & $<30 \mathrm{~m}$ & $40-470 m$ & $<70 \mathrm{~m}$ & $\begin{array}{l}\text { Asymmetric, } \\
\text { steeper proximal } \\
\text { slope (18deg vs } \\
\text { 11deg distal) }\end{array}$ & $\begin{array}{l}\text { Poorly-sorted } \\
\text { sandy muddy } \\
\text { gravel } \\
\text { interpreted as } \\
\text { glacigenic } \\
\text { diamicton }\end{array}$ & $\begin{array}{l}\text { Subaqueous } \\
\text { grounding line } \\
\text { moraines }\end{array}$ & $\begin{array}{l}\text { Dix \& Duck } \\
(2000)\end{array}$ \\
\hline $\begin{array}{l}\text { More, western } \\
\text { Norway }\end{array}$ & $\begin{array}{l}\text { Perpendicular to } \\
\text { ice flow, slightly } \\
\text { convex or } \\
\text { concave }\end{array}$ & $3-6 m$ & $20-30 m$ & $\begin{array}{l}250 \mathrm{~m}- \\
10 \mathrm{~km}\end{array}$ & $50-1200 \mathrm{~m}$ & $\mathrm{~N} / \mathrm{A}$ & $\begin{array}{l}\text { Sandy diamicton, } \\
\text { sorted } \\
\text { sediments, } \\
\text { isolated clasts; } \\
\text { stacked, sheared, } \\
\text { faulted, liquified, } \\
\text { diapir structures }\end{array}$ & $\begin{array}{l}\text { Formation at a } \\
\text { retreating glacier } \\
\text { grounding line }\end{array}$ & $\begin{array}{l}\text { Larsen et al. } \\
\text { (1991) }\end{array}$ \\
\hline $\begin{array}{l}\text { Swedish } \\
\text { mountains }\end{array}$ & $\begin{array}{l}\text { Cross-valley, } \\
\text { straight or } \\
\text { slightly convex } \\
\text { downvalley }\end{array}$ & $1-10 m$ & N/A & $\begin{array}{l}10 \text { 's- } \\
1000 \text { 's m }\end{array}$ & N/A & $\mathrm{N} / \mathrm{A}$ & N/A & $\begin{array}{l}\text { Formed at terminus } \\
\text { of water-terminating } \\
\text { glaciers flowing up- } \\
\text { valley }\end{array}$ & $\begin{array}{l}\text { Heyman \& } \\
\text { Hattestrand } \\
(2006)\end{array}$ \\
\hline $\begin{array}{l}\text { Quebec, } \\
\text { Canada }\end{array}$ & $\begin{array}{l}\text { Perpendicular to } \\
\text { ice flow, some } \\
\text { chevron shaped }\end{array}$ & $1-10 m$ & N/A & $\mathrm{N} / \mathrm{A}$ & $60-400 m$ & $\begin{array}{l}\text { Symmetrical or } \\
\text { asymmetrical }\end{array}$ & $\begin{array}{l}\text { Predominantly } \\
\text { glaciofluvial } \\
\text { sediments, often } \\
\text { glaciotectonised }\end{array}$ & $\begin{array}{l}\text { Deposition from } \\
\text { meltwater flowing } \\
\text { through transverse } \\
\text { subglacial cavities }\end{array}$ & $\begin{array}{l}\text { Beaudry \& } \\
\text { Prichonnet } \\
\text { (1991) }\end{array}$ \\
\hline $\begin{array}{l}\text { Swedish } \\
\text { mountains }\end{array}$ & $\begin{array}{l}\text { Transverse to } \\
\text { iceflow, straight } \\
\text { or slightly } \\
\text { concave up- } \\
\text { valley }\end{array}$ & $<4 m$ & $1-20 m$ & $<200 m$ & $30-50 m$ & $\begin{array}{l}\text { Symmetrical or } \\
\text { asymmetrical }\end{array}$ & $\begin{array}{l}\text { Mainly firm, } \\
\text { sandy till, rare } \\
\text { glaciofluvial } \\
\text { material }\end{array}$ & $\begin{array}{l}\text { Subaqueous } \\
\text { moraines formed at } \\
\text { or near the ice } \\
\text { margin }\end{array}$ & $\begin{array}{l}\text { Borgstrom } \\
\text { (1979) }\end{array}$ \\
\hline $\begin{array}{l}\text { Pasvik, north } \\
\text { Norway }\end{array}$ & $\begin{array}{l}\text { Transverse to } \\
\text { iceflow }\end{array}$ & $<10 \mathrm{~m}$ & $50 \mathrm{~m}$ & $1 \mathrm{~km}$ & $\begin{array}{l}10 \text { 's- } \\
100 \text { 's m }\end{array}$ & $\begin{array}{l}\text { Steeper distal } \\
\text { side }\end{array}$ & $\begin{array}{l}\text { Proximal side - } \\
\text { homogeneous } \\
\text { sandy material, } \\
\text { distal side - } \\
\text { interbedded till } \\
\text { and sorted } \\
\text { sediments }\end{array}$ & $\begin{array}{l}\text { Subaqueous } \\
\text { glaciofluvial } \\
\text { deposition along ice } \\
\text { margin, from } \\
\text { debouching central } \\
\text { conduit }\end{array}$ & Sollid (1989) \\
\hline Finland & $\begin{array}{l}\text { Straight, } \\
\text { transverse to } \\
\text { iceflow }\end{array}$ & $1-3 m$ & $10-20 m$ & $\begin{array}{l}100 \mathrm{~m}- \\
2 \mathrm{~km}\end{array}$ & $60-180 m$ & $\begin{array}{l}\text { Symmetric or } \\
\text { steeper distal } \\
\text { side }\end{array}$ & $\begin{array}{l}\text { Sandy and poorly- } \\
\text { sorted till }\end{array}$ & $\begin{array}{l}\text { Squeezing of } \\
\text { subglacial till up into } \\
\text { subglacial crevasses } \\
\text { following surge } \\
\text { advance }\end{array}$ & $\begin{array}{l}\text { Zilliacus } \\
\text { (1989) }\end{array}$ \\
\hline
\end{tabular}


Table 2:

\begin{tabular}{|c|c|c|c|c|c|c|}
\hline Composition & Character & Facies & Description and Code & Interpretation & Environment & References \\
\hline \multirow[t]{2}{*}{ Diamicton } & Massive & 1 & $\begin{array}{l}\text { Diamicton, matrix or } \\
\text { clast-supported, massive } \\
(\mathrm{Dmm} / \mathrm{Dcm})\end{array}$ & $\begin{array}{l}\text { Debris flow or } \\
\text { submarginal }\end{array}$ & $\begin{array}{l}\text { Subglacial deposition /emplacement } \\
\text { directly from the glacier sole }\end{array}$ & \multirow[t]{2}{*}{$\begin{array}{l}\text { Zielinski et al (1996); Brazier } \\
\text { et al (1998); Blake (2000) }\end{array}$} \\
\hline & Stratified & 2 & $\begin{array}{l}\text { Diamicton, matrix or } \\
\text { clast-supported, } \\
\text { stratified (Dms/Dcs) }\end{array}$ & Debris flow & Ice-marginal, high energy, episodic & \\
\hline \multirow[t]{4}{*}{ Gravel } & $\begin{array}{l}\text { Massive, } \\
\text { sorted }\end{array}$ & 3 & $\begin{array}{l}\text { Gravel, massive, sorted } \\
\text { (Gms) }\end{array}$ & Debris flow & \multirow{4}{*}{$\begin{array}{l}\text { Ice-proximal, high energy, episodic. } \\
\text { Subaerial or subaqueous. Iceberg } \\
\text { overturning }\end{array}$} & \multirow{4}{*}{$\begin{array}{l}\text { Lowe (1982); Lonne(1993; } \\
\text { 1995); Nemec et al (1999); } \\
\text { Blake (2000); Winsemann et } \\
\text { al (2004) }\end{array}$} \\
\hline & $\begin{array}{l}\text { Massive, } \\
\text { unsorted or } \\
\text { openwork }\end{array}$ & 4 & $\begin{array}{l}\text { Gravel, massive or } \\
\text { openwork (Gm/Go) }\end{array}$ & $\begin{array}{l}\text { High-density debris flow, } \\
\text { or subaerial glaciofluvial }\end{array}$ & & \\
\hline & $\begin{array}{l}\text { Normally } \\
\text { graded }\end{array}$ & 5 & $\begin{array}{l}\text { Gravel, fining-upwards } \\
\text { (Gfu) }\end{array}$ & Low-density debris flow & & \\
\hline & $\begin{array}{l}\text { Reverse } \\
\text { graded }\end{array}$ & 6 & $\begin{array}{l}\text { Gravel, coarsening- } \\
\text { upwards (Gcu) }\end{array}$ & Debris flow & & \\
\hline \multirow[t]{3}{*}{ Sand } & Massive & 7 & Sand, massive (Sm) & Hyperconcentrated flow & \multirow{3}{*}{$\begin{array}{l}\text { Relatively high velocity, turbulent flow; } \\
\text { ice-proximal fan lobes or aprons, } \\
\text { possibly with channelised surface }\end{array}$} & \multirow{3}{*}{$\begin{array}{l}\text { Blake (2000); Fard (2001); } \\
\text { Bennett et al., (2002); } \\
\text { Etienne et al., (2006) }\end{array}$} \\
\hline & $\begin{array}{l}\text { Planar cross- } \\
\text { bedded }\end{array}$ & 8 & $\begin{array}{l}\text { Sand, planar, horizontal, } \\
\text { or cross bedded, } \\
\text { upwards-fining, or } \\
\text { laminated } \\
\text { (Sp/Sh/Sc/Suf/Sl) }\end{array}$ & $\begin{array}{l}\text { Apron or fan deposits } \\
\text { (overbank) }\end{array}$ & & \\
\hline & $\begin{array}{l}\text { Trough cross- } \\
\text { bedded }\end{array}$ & 9 & $\begin{array}{l}\text { Sand, trough-cross } \\
\text { bedded or upward- } \\
\text { coarsening (St/Su) }\end{array}$ & Channel sediments & & \\
\hline \multirow[t]{2}{*}{ Silt \& clay } & Massive & 10 & Fines, massive $(\mathrm{Fm})$ & Hyperconcentrated flow & Distal runout from ice-proximal source & \multirow{2}{*}{$\begin{array}{l}\text { Lonne (1993); Bennett et al. } \\
\text { (2002); Thomas and Chiverrell } \\
\text { (2006) }\end{array}$} \\
\hline & Laminated & 11 & $\begin{array}{l}\text { Fines, laminated or } \\
\text { varved }(\mathrm{Fl} / \mathrm{Flv})\end{array}$ & Basin muds & $\begin{array}{l}\text { Suspension settling distal to ice margin - } \\
\text { basin muds; proximal sedimentation in } \\
\text { quiet water, low sedimentation rate }\end{array}$ & \\
\hline
\end{tabular}




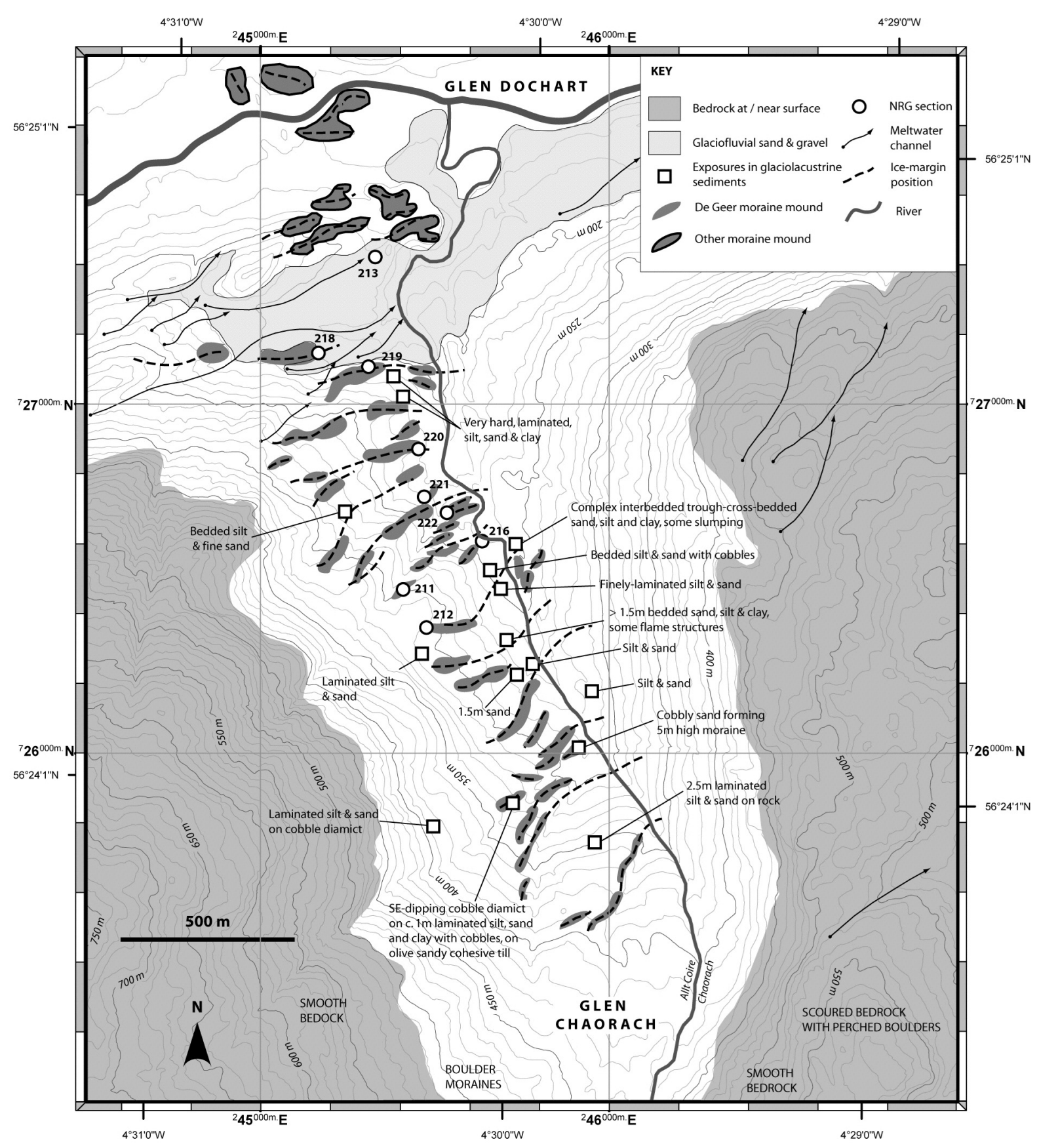

Figure 2: 


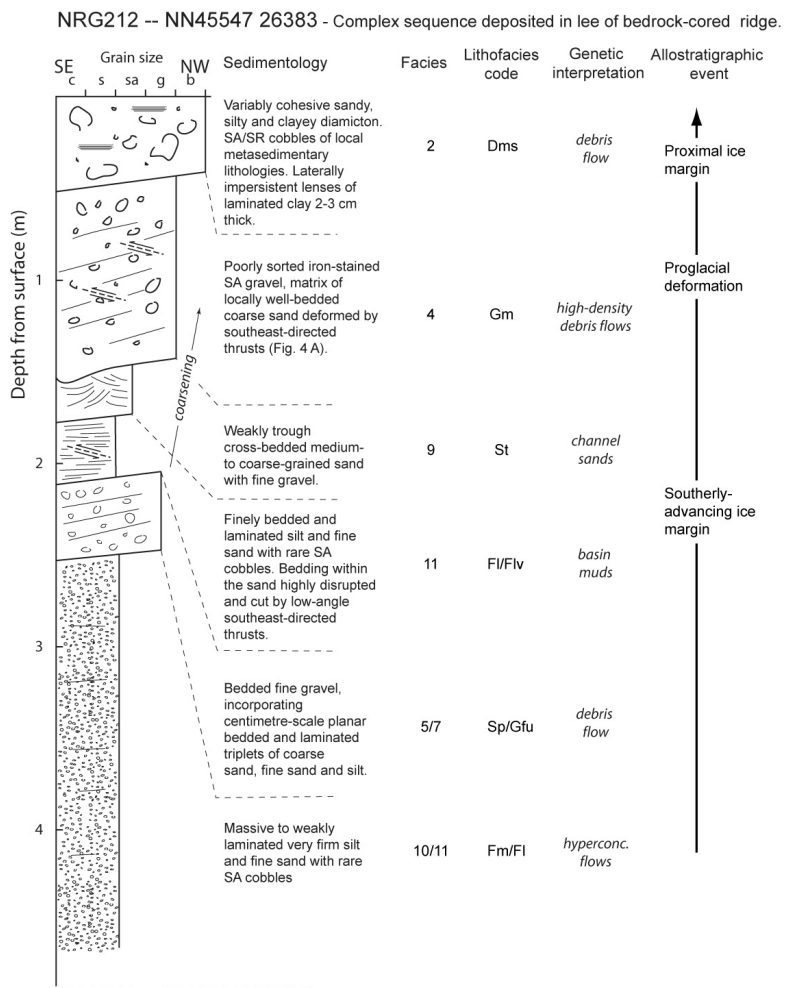

NRG216 -- NN45660 26597 - 2-3 m-high section through terrace forming bank of Allt Coire Chaorach. Complex sequence of alternating units showing abrupt changes in grain size

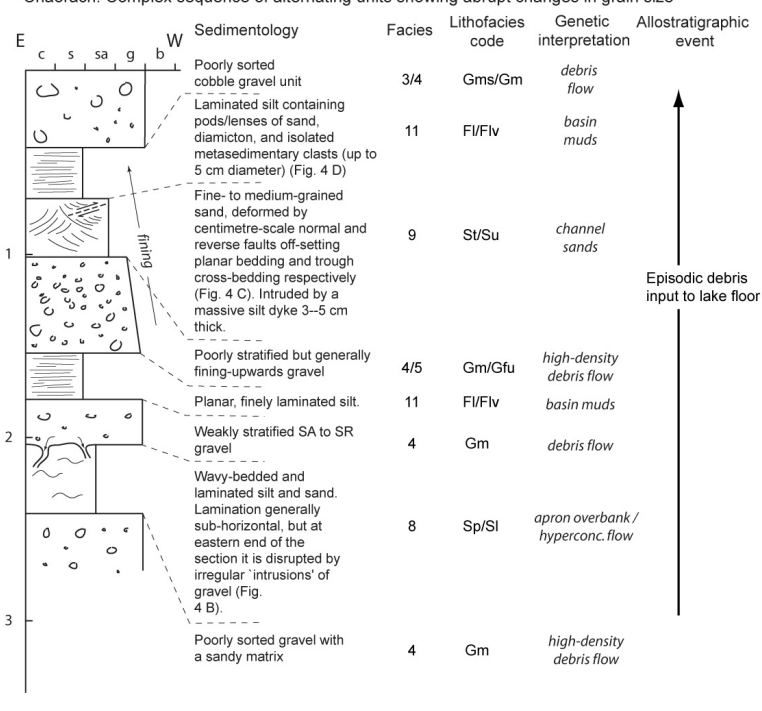

NRG222 -- NN45534 26708 - 4 m-high section on the northern flank of a mound orientated perpendicular to the general trend of the valley axis.
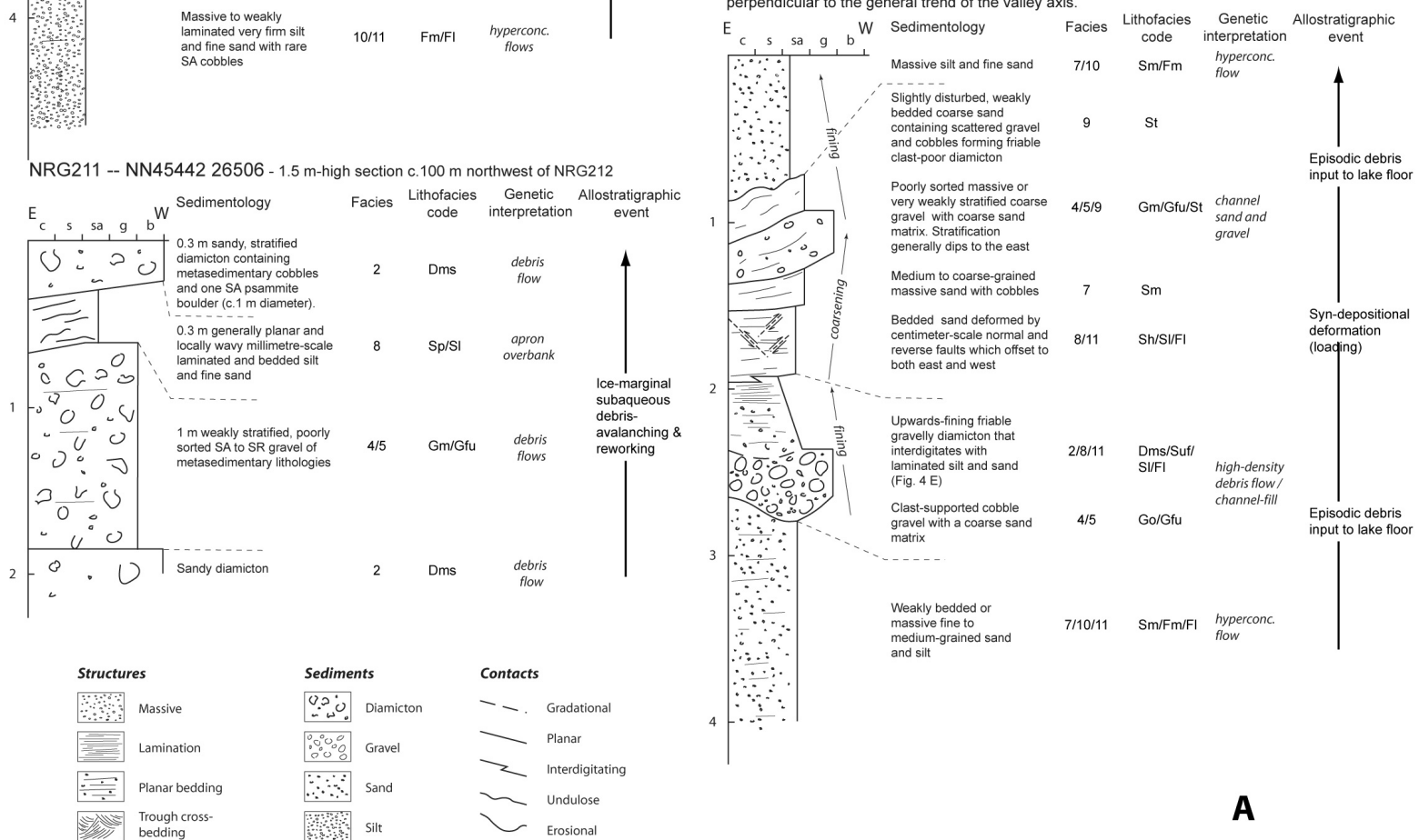

medium-grained sand

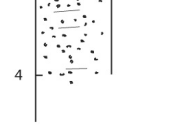

Figure 3: A 
NRG221 -- NN45500 26709 - 2.5 m-high, 4.5 m-wide cross-section through a valley-floor ridge,

NRG219 -- NN45307 27106 - $40 \mathrm{~m}$ long trackside section exposing a 2.5 -- $3 \mathrm{~m}$ thick
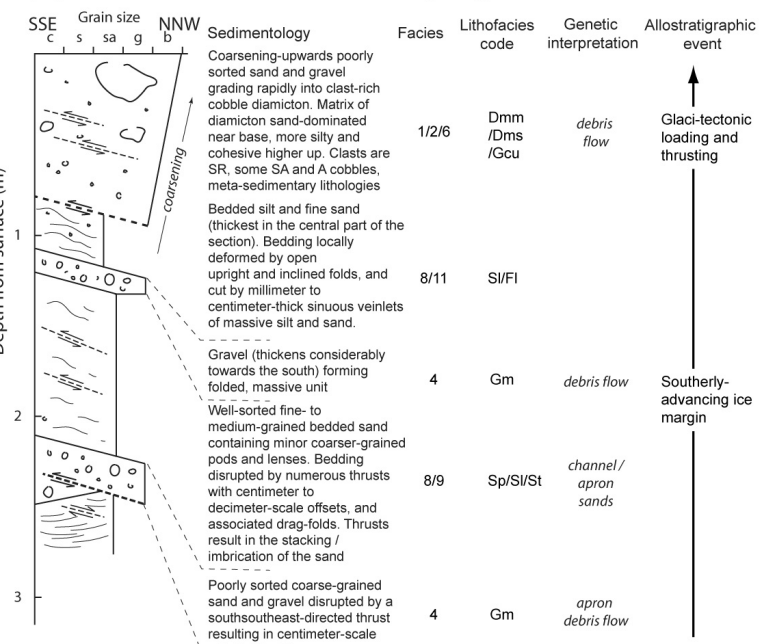
sequence of interbedded silt and gravel units.

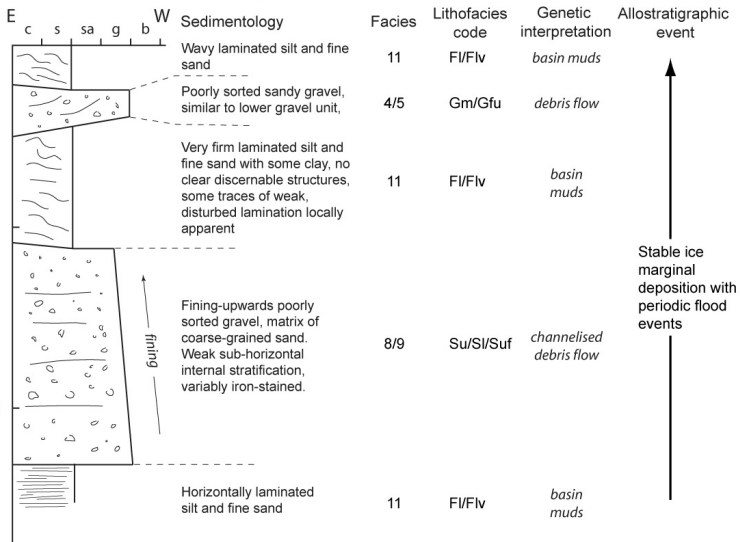

NRG218 -- NN45163 27168 - $2 \mathrm{~m}$ high section in northeast end of a linear mound located at the mouth of Glen Chaorach, revealing a sequence of interbedded sand and gravel units

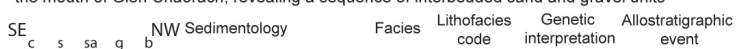
resulting in centimeter-scale
offset of bedding.
$\begin{aligned} & \text { Beddded medium-grained sand } \\ & \text { deformed by small-scale }\end{aligned}$, $\quad$ St $\quad \begin{gathered}\text { channel/ } \\ \text { apron } \\ \text { sands }\end{gathered}$

NRG220 -- NN45482 26853 - $1.5 \mathrm{~m}$ high section in the southern side of a valley-floo ridge close to NRG 221
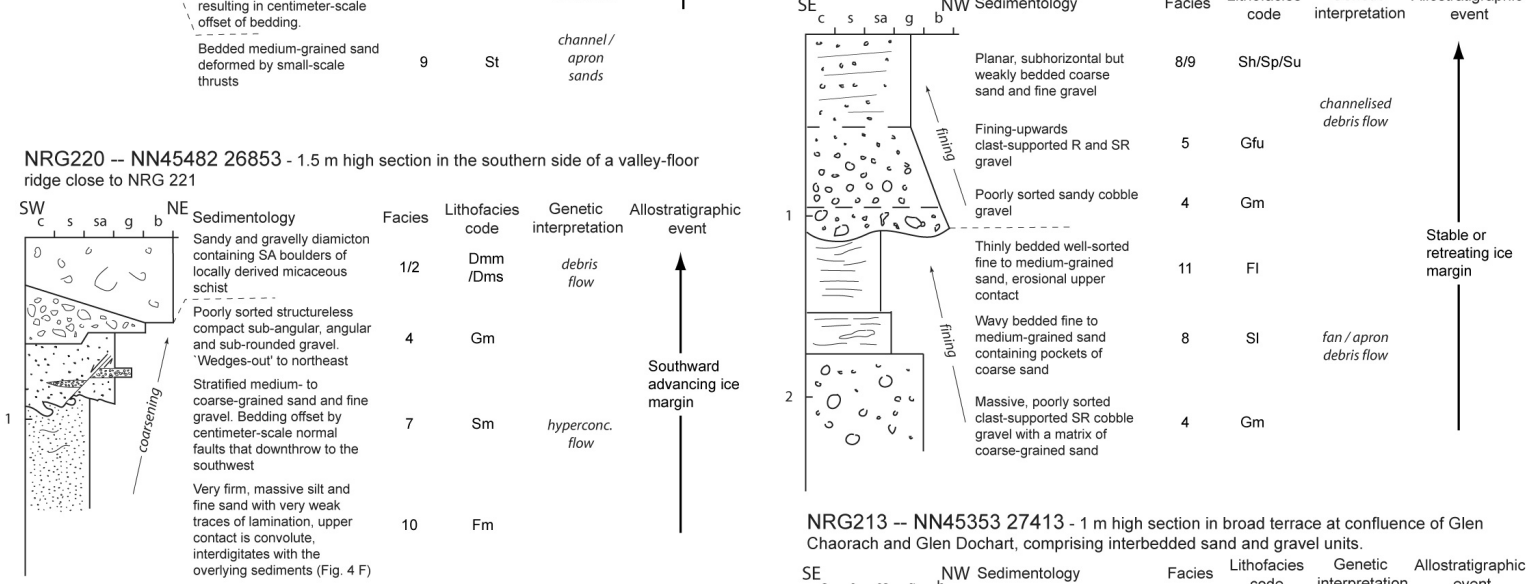

\begin{tabular}{|c|c|c|c|c|}
\hline Structu & & Sedime & & Contacts \\
\hline & Massive & $\because 200$ & Diamicton & - Gradational \\
\hline 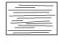 & Lamination & $\begin{array}{l}\because \because 00 \\
\because 00 \\
000\end{array}$ & Gravel & Planar \\
\hline$\doteqdot$ & Planar bedding & $\because$ & Sand & $\begin{array}{l}\text { Interdigitating } \\
\text { Undulose }\end{array}$ \\
\hline 翏这 & $\begin{array}{l}\text { Trough cross- } \\
\text { bedding }\end{array}$ & Pl & Silt & Erosional \\
\hline
\end{tabular}

NRG213 -- NN45353 27413 - $1 \mathrm{~m}$ high section in broad terrace at confluence of Glen Chaorach and Glen Dochart, comprising interbedded sand and gravel units.

\begin{tabular}{|c|c|c|c|c|c|}
\hline $\mathrm{SE}_{c}$, s sa $g$, $b^{\mathrm{NV}}$ & Sedimentology & Facies & $\begin{array}{l}\text { Lithofacies } \\
\text { code }\end{array}$ & $\begin{array}{c}\text { Genetic } \\
\text { interpretation }\end{array}$ & $\begin{array}{c}\text { Allostratigraphic } \\
\text { event }\end{array}$ \\
\hline \multirow{5}{*}{ 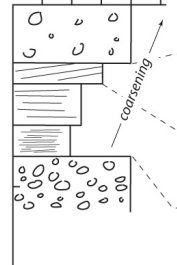 } & $\begin{array}{l}\text { Poorly sorted Rand SR gravel| } \\
\text { with a sand-dominated matrix }\end{array}$ & 4 & $\mathrm{Gm}$ & $\begin{array}{l}\text { subaerial } \\
\text { debris flow }\end{array}$ & \multirow{5}{*}{$\begin{array}{l}\text { Subaerial } \\
\text { deglacial } \\
\text { glaciofluvial } \\
\text { terrace }\end{array}$} \\
\hline & $\begin{array}{l}\text { Cross-bedded medium to } \\
\text { coarse-grained sand } \\
\text { cross-stratififaction dips } 8^{\circ} \\
\text { towards } 125^{\circ} \text { (southeast) }\end{array}$ & 8 & $\mathrm{Sp} / \mathrm{Sc}$ & channel/fan & \\
\hline & $\begin{array}{l}\text { Weakly bedded fine to } \\
\text { medium-grained sand } \\
\text { Laminated and wavy-bedded }\end{array}$ & 8 & $\mathrm{Sh} / \mathrm{SI}$ & $\begin{array}{l}\text { overbank } \\
\text { deposits }\end{array}$ & \\
\hline & silt and fine sand & 11 & $\mathrm{Fl}$ & & \\
\hline & $\begin{array}{l}\text { llast-supported gravel with } \\
\text { friable matrix of } \\
\text { coarse-grained sand. }\end{array}$ & 4 & $\mathrm{Gm}$ & $\begin{array}{l}\text { glaciefluvial } \\
\text { bedload }\end{array}$ & \\
\hline
\end{tabular}

Figure 3: B 

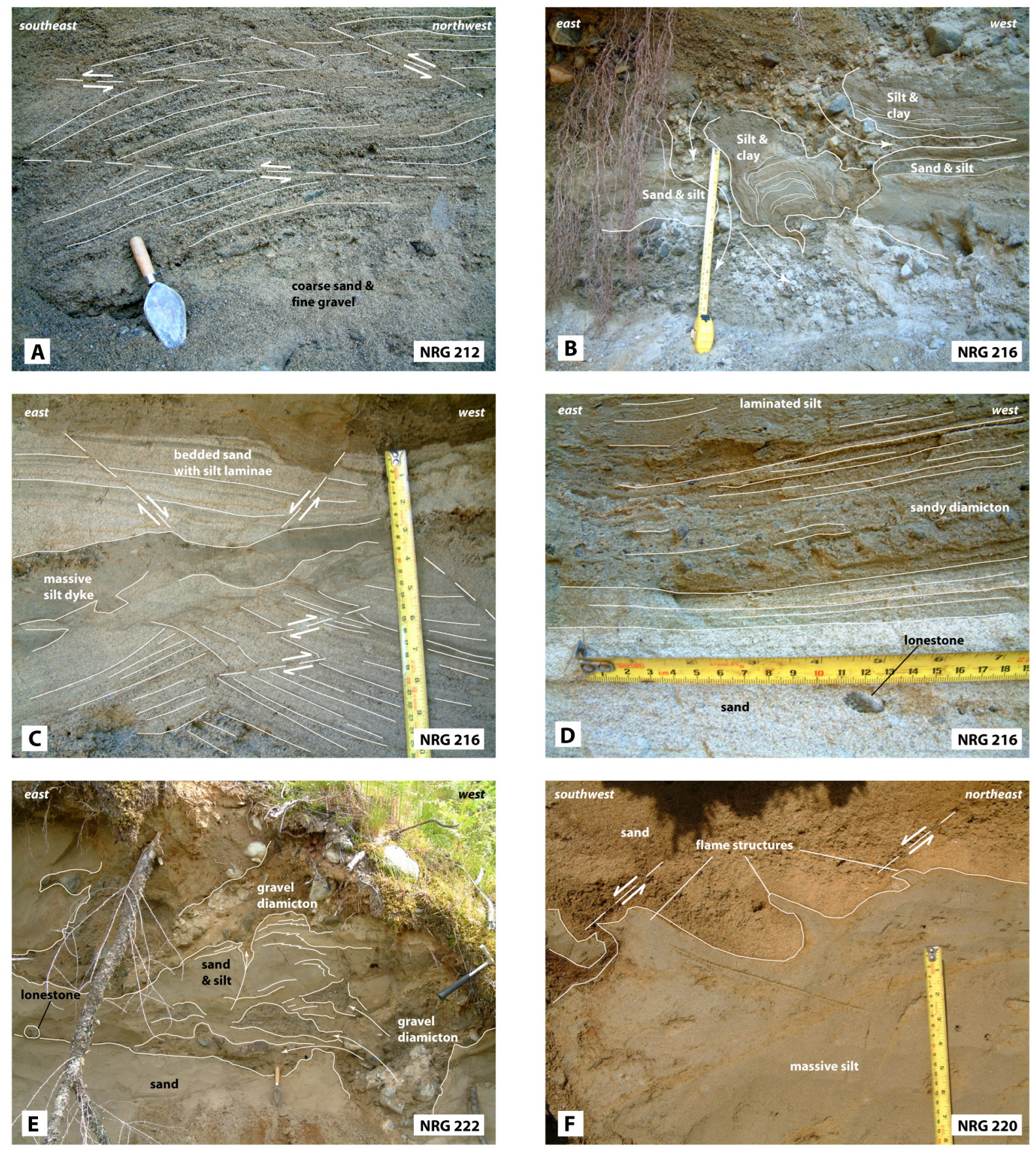

Figure 4: 

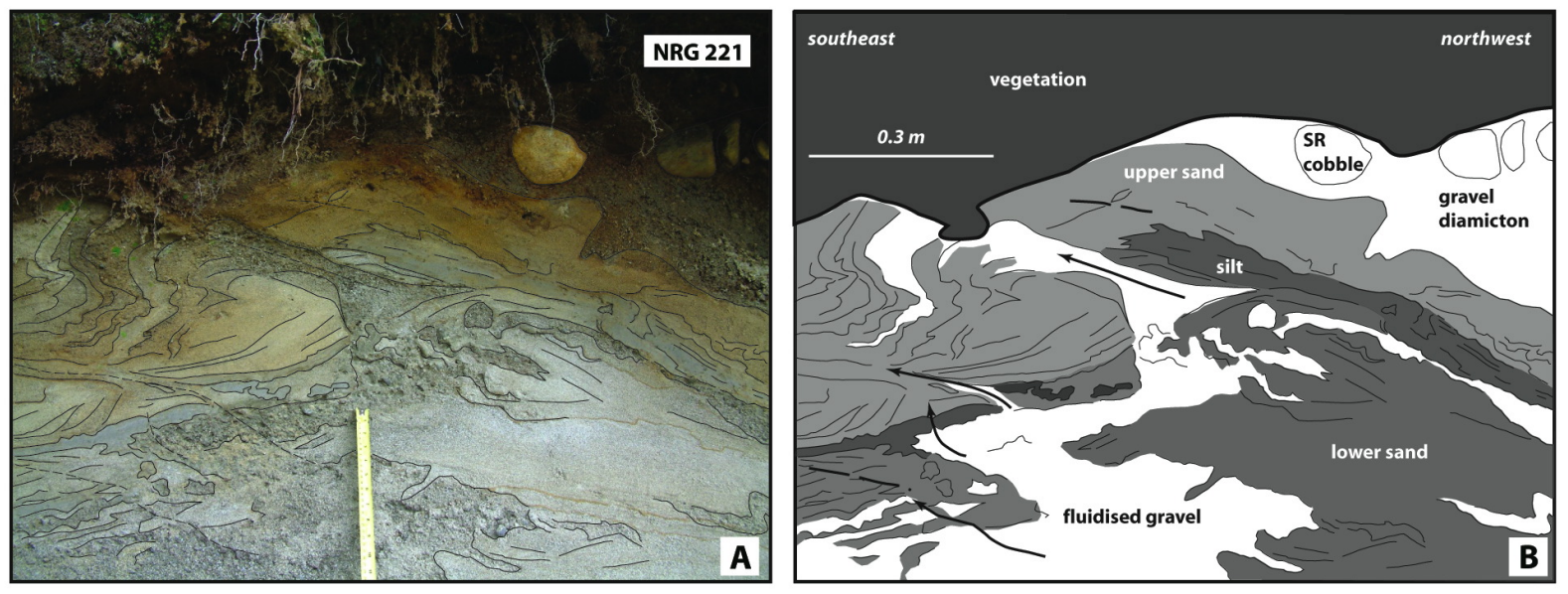

Figure 5:

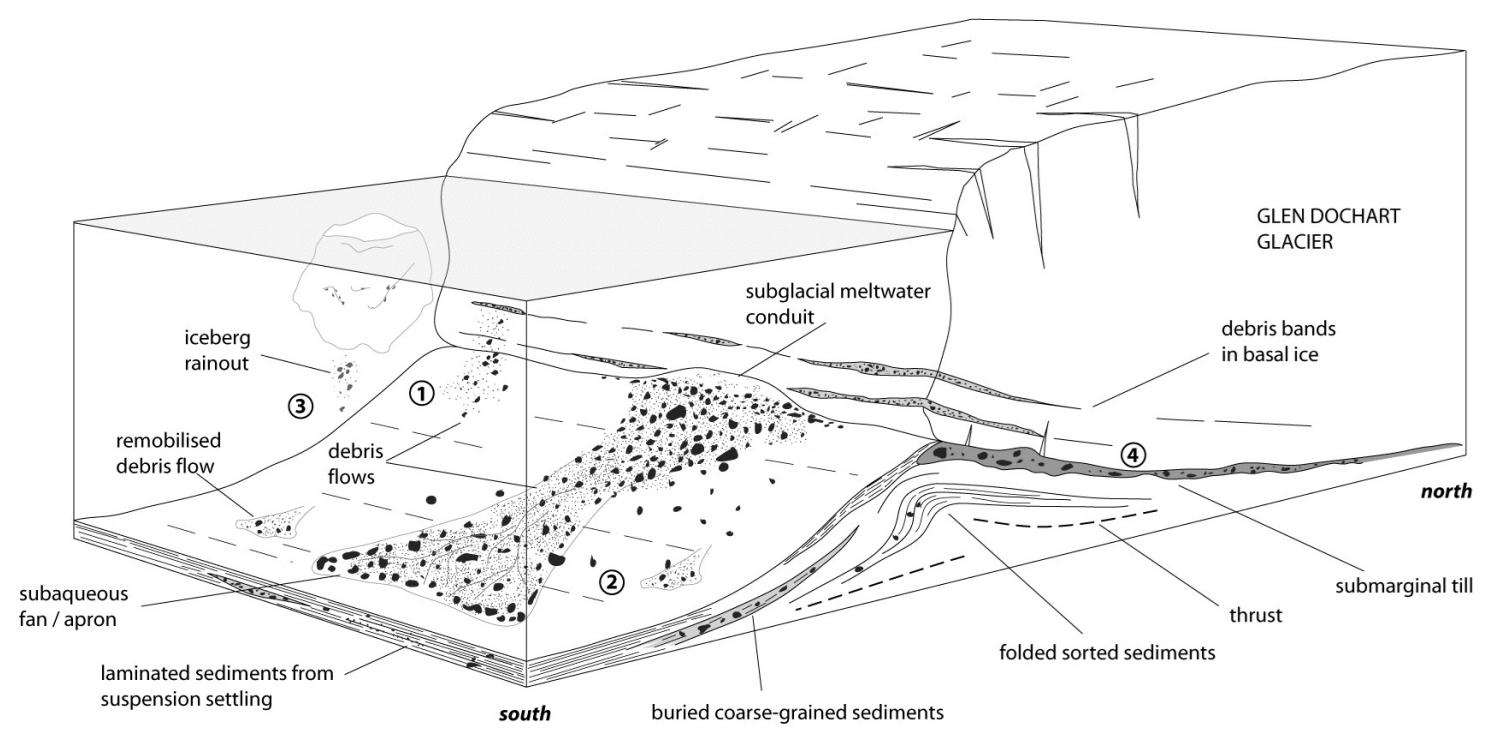

Figure 6: 

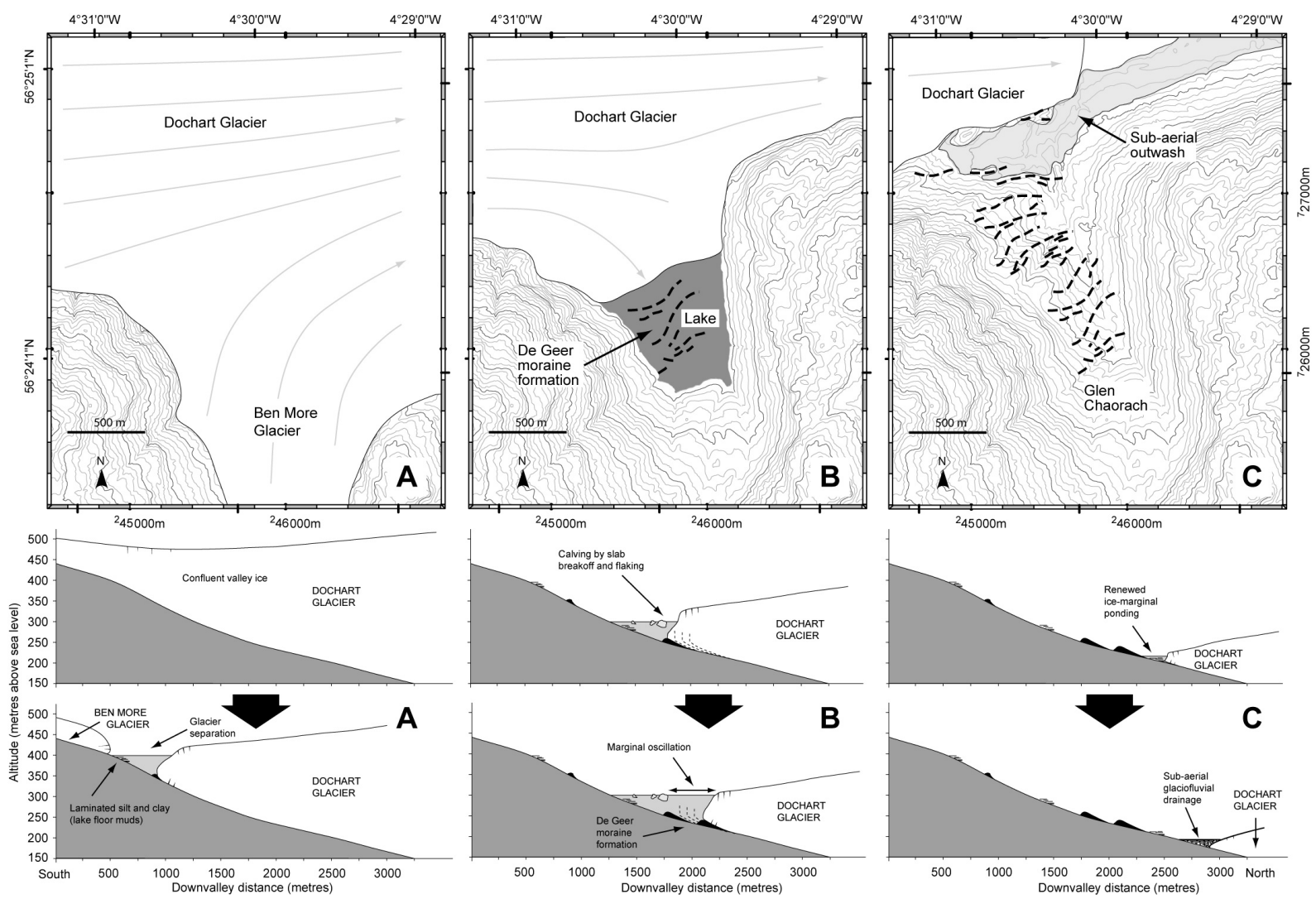

Figure 7: 